\title{
Influence of Product, Price and Promotion on Purchase Decision of Toyota Agya Car with Brand Image as Intervening Variables in Padang City
}

\author{
Ragiev Zubarjan ${ }^{1 *}$, Idris ${ }^{2}$ \\ ${ }^{1,2}$ Universitas Negeri Padang, Padang, Indonesia \\ *Corresponding author. Email: ragievz@gmail.com
}

\begin{abstract}
This study aims to determine the effect of products, prices and promotions on purchasing decisions for Toyota Agya cars with brand image as an intervening variable in the city of Padang. This study used a survey approach using a questionnaire to collect data from Toyota Agya car users in Padang City. The data analysis technique used the PLSSEM approach. The findings show that product, price and promotion have a positive and significant effect on purchasing decisions. Products, prices and promotions have apositive and significant effect on brand image. Brand image has a positive and significant effect on brand image. Has a positive and Significant impact. Price on purchasing decisions through brand image has a positive and significant effect and promotion on purchasing decisions through brand image has a positive and significant effect.
\end{abstract}

Keywords: Product, Price, Promotion, Purchase decision, Brand image, Purchase decision.

\section{INTRODUCTION}

The people's need for very large cars is a phenomenon in today's society's needs. There are many considerations before making a purchase decision for consumers, various considerations from consumers when choosing a car such as motivation and different perceptions. This is the cause for every automotive company that has an obligation to know which cars are a need for potential customers. Very high market demand can be seen because all car manufacturers seem to be competing in making new innovations, in continuous designs and models and also the many advertisements in many media.

Understanding consumer purchasing behavior will help marketers to obtain marketing success, which can be seen in sales volume showing the high and low level of purchase decisions (Shande, 2014: 1) [1]. The study of automotive consumer behavior is very important for marketing both theoretically and practically, in order to find out the keys to increasing sales volume and to answer the needs of automotive consumers in making purchasing decisions (Alamgir, 2014: 144) [2]. The determining factor for the success of company management, especially in its marketing, is high consumer purchasing decisions as seen from the increased sales volume of these products (Akinyeke, et al 2012:3) [3]. The product factor is a concern for consumers when making decisions because it has an attractive appearance, has good quality and is unique, which increases consumer interest in buying. This is a driving force for the company to maintain its business so that it is able to compete in the industry with other competitors. Price plays a role as the main determinant for buyers in deciding whether the product already has an appropriate price or not. Pricing decisions are always buyer-oriented. (Kotler and Armstrong, 2012) [5]. The price is below the product value, so consumers will buy the product (Wijaya, 2017) [6]. Research conducted by Wijaya (2017) [6] and Andrianto (2013) [7] states that the price has a positive. effect on purchasing decisions.

Another factor that determines purchasing decisions is promotion. Making attractive promotions can make it easier for consumers to make decisions on product purchases. This promotion will be able to shape consumer behavior in the concept of decisions, purchases. And research that has been conducted by Andrianto (2013) [7] states that promotion has a significant positive effect on purchasing decisions. Each individual has different ways of making purchasing decisions. The world community who wants everything that can be obtained in a fast and instant way in order to 
increase social status has solidified their decision to buy a car. The various choices of car products that exist today cause consumers to be careful in making purchasing decisions on the type and brand of car that suits them.Researchers used brand image as an intervening variable. Every company has an obligation to have a strong brand image. Saladin (2010) [9] also states that a brand is a number of impressions that customers or consumers get in the form of emotional and functional benefits that are felt so that a special position will appear in their memory. Next, Rangkuti (2004) [10] reveals that a brand image is a set of brand associations that are formed and attached to the minds of consumers. Based on this background, the researcher wants to examine how the effect of product, price, and promotion on the decision to buy a Toyota Agya car with brand image as.an intervening variable in the city of Padang.

\section{METHODS}

The population taken in this study are people who know about the Toyota Agya product brand and have not bought it. Determination of the sample in this study, using a sample selection method of non-probability sampling. Given the large number of Toyota Agya car users and due to time constraints, the sampling method used is a non-probability sampling method with purposive sampling technique, a technique that determines the research sample with certain considerations so that the data obtained will be more representative (Sugiono, 2012) [11]. Based on the sample formula that will be used as respondents from this study are as many as 360 people of Padang City who have plans to purchase Toyota Agya products.

Table 1. Characteristics of Respondents based on gender

\begin{tabular}{|c|c|c|c|}
\hline No & Gender & Frequency & Percentage \% \\
\hline 1 & Laki-laki & 227 & $63,1 \%$ \\
\hline 2 & Perempuan & 133 & $36,9 \%$ \\
\hline \multicolumn{2}{|c|}{ Total } & $\mathbf{3 6 0}$ & $\mathbf{1 0 0 \%}$ \\
\hline
\end{tabular}

Table 2. Characteristics of Respondents by Age Group

\begin{tabular}{|c|c|c|c|}
\hline No & Age Group & Frequency & Percentage \% \\
\hline 1 & $<20$ Tahun & 11 & $3,1 \%$ \\
\hline 2 & 20-30 Tahun & 185 & $51,4 \%$ \\
\hline 3 & 31-40 Tahun & 104 & $28,9 \%$ \\
\hline 4 & 41-50 Tahun & 60 & $16,7 \%$ \\
\hline \multicolumn{2}{|c|}{ Total } & $\mathbf{3 6 0}$ & $\mathbf{1 0 0 \%}$ \\
\hline
\end{tabular}

Table 3 Characteristics of Respondents Based on Education

\begin{tabular}{|c|l|c|c|}
\hline No & Education & Frequency & Percentage \% \\
\hline 1 & SLTP Sederajat & 0 & $0 \%$ \\
\hline 2 & SLTA Sederajat & 71 & $19,7 \%$ \\
\hline 3 & Diploma & 63 & $17,5 \%$ \\
\hline 4 & Strata & 226 & $62,8 \%$ \\
\hline \multicolumn{2}{|c|}{ Total } & $\mathbf{3 6 0}$ & $\mathbf{1 0 0 \%}$ \\
\hline
\end{tabular}

Tabel 4 Characteristics of Respondents Based on Income

\begin{tabular}{|c|c|c|c|}
\hline No & Income & Frequency & Percentage \% \\
\hline 1 & $<$ Rp.1.000.000 & 0 & $0 \%$ \\
\hline 2 & $\begin{array}{l}\text { Rp.1.000.000- } \\
\text { Rp.2.000.000 }\end{array}$ & 20 & $5,6 \%$ \\
\hline 3 & $\begin{array}{c}\text { Rp.2.000.000- } \\
\text { Rp.5.000.000 }\end{array}$ & 176 & $48,9 \%$ \\
\hline 4 & $>$ Rp.5.000.000 & 164 & $45,6 \%$ \\
\hline & Total & 360 & $100 \%$ \\
\hline
\end{tabular}

Furthermore, this research will be analysed using the PLS-SEM approach. In this study, we used Smart PLS version 3 to test the conceptual framework proposed in the hypothesis. Analyses are presented in a transparent and sequential manner, allowing. Clarity in the conceptual framework and results. Hypothesis testing is carried out by using the Structural Equation Model (SEM) approach using smartPLS software based on components or variances. PLS is an alternative approach that shifts from the covariance-based SEM approach, which generally tests causality / theory while PLS is more of a mediative model.

\section{RESULTS AND DISCUSSION}

SmartPLS provides 3 main results: outer loading for model measurements, path coefficients for structural models and R2 values for latent variables. Assesment of!the measurement model additionally involves the reliability of the composite testing for internal consistency, the reliability of individual indicators and the mean variance extracted to visualize for convergent validity.

The first step focuses on confirming valid and reliable construct steps. Hypothesis checking involving structural relationships between constructs are reliable ifothe measure model that describes however the consctructs meet the standards of validity and reliability. Cronbach alfa shows that the latent variable contains a worth greater than 0.7 , indicating high reliability supported the connection between the determined variable indicators. The composite reliability test value is larger than 0.7 , that indicates a high level of reliability and considered satisfaction determine focused validity, this study considers the typical variance extracted and outer loadings. The results show that the standardized 
outer loading bigger than 0.621. AVE value is higher than 0.5 , which indicates an appropriate level of community. Values indicates that the constructs justify more than 0.5 the variance of the indicator.

Tabel 5. Validity and Reliability Test

\begin{tabular}{|l|c|c|c|c|}
\hline & $\begin{array}{l}\text { Cronbach's } \\
\text { Alpha }\end{array}$ & rho_A & $\begin{array}{l}\text { Composite } \\
\text { Reliability }\end{array}$ & $\begin{array}{l}\text { Average } \\
\text { Variance } \\
\text { Extracted } \\
\text { (AVE) }\end{array}$ \\
\hline Produk (X1) & 0.954 & 0.955 & 0.959 & 0.627 \\
\hline Harga (X2) & 0.906 & 0.910 & 0.924 & 0.604 \\
\hline Promosi (X3) & 0.891 & 0.897 & 0.913 & 0.568 \\
\hline $\begin{array}{l}\text { Keputusan } \\
\text { pembelian (Y) }\end{array}$ & 0.917 & 0.918 & 0.935 & 0.707 \\
\hline Citra merek (Z) & 0.948 & 0.949 & 0.955 & 0.637 \\
\hline
\end{tabular}

Table 5 shows that the VIF of the construct value is below the threshold of 5, which indicates that the collinearity between constructs is not a problem in the structural model. The next step is to determine the value of the R.Square Analysis Table IV shows the value of $\mathrm{R}$ Square which shows the moderate level of each variable.

\section{Hypothesis 1}

This indicates that the product has a positive and significant effect on purchasing decisions ( $p$-value < 0.005 , namely 0.032 ), this indicates that $\mathrm{H} 1$ is accepted. The analysis results show that the product has a positive and significant effects on brand image. This means that the better the product, the better the brand image. The opposite happens when the product is not suitable.

\section{Hypothesis 2}

Furthermore, price has a positive and significant effect on purchasing decisions ( $p$-value $<0.005$, namely 0.032 ), this indicates that $\mathrm{H} 2$ is accepted. The results of the analysis show that price has a positive and significant effects on. Brand image. This means that the more appropriate the product price, the more the brand image will increase. The opposite happens when prices do not match.

\section{Hypothesis 3}

Furthermore, promotion has appositive and significant effect on purchasing decisions (p-value < 0.005 , namely 0.030 ), this indicates that $\mathrm{H} 3$ is accepted. The results of the analysis show that promotion has a positive and significant effects on brand image. This means that the better the promotion, the more the brand image will be. The opposite happens when promotion decreases.

\section{Hypothesis 4}

Furthermore, the product has a positive and significant effect on brand image ( $\mathrm{p}$-value $<0.005$, namely 0.000 ), this indicates that $\mathrm{H} 4$ is accepted. The results of the analysis show that the product has a positive effect on purchasing decisions. This means that the better and more appropriate the product, the more purchasing decisions will increase. The opposite happens if the product decreases.

\section{Hypothesis 5}

Furthermore, price has a positive and significant effect on brand image ( $\mathrm{p}$ - value $<0.005$, namely 0.014 ), this indicates that $\mathrm{H} 5$ is accepted. The results of the analysis show that price has a positive effect on purchasing decisions. This means that the more appropriate the price, the more purchasing decisions increase. The opposite happens if prices do not match.

\section{Hypothesis 6}

Furthermore, promotion has a positive and significant effect on brand image ( $\mathrm{p}$-value $<0.005$, namely 0.002), this indicates that H6 is accepted. The results of the analysis show that promotion has a positive and significant effect on purchasing decisions. This means that the better the promotion, the more purchasing decisions will be made.

\section{Hypothesis 7}

Furthermore, brand image has a positive and significant effect on purchasing decisions (p-value < 0.005 , namely 0.000 ), this indicates that $\mathrm{H} 7$ is accepted. The results of the analysis show that promotion has a positive and significant effects on purchasing decisions.

\section{Hypothesis 8}

Furthermore, products through brand image have a positive and significant effect on purchasing decisions (p-value $<0.005$, namely 0.000 ), this indicates that $\mathrm{H} 8$ is accepted. The results of the analysis show that brand image has a positive and significant effect on purchasing decisions. This means thatvthe stronger brand image, the higher the purchasing decision. The opposite happens if the brand image weakens.

\section{Hypothesis 9}

Furthermore, price through brand image has a positive and significant effect on purchasing decisions ( $\mathrm{p}$-value $<$ 0.005 , namely 0.033 ), this indicates that $\mathrm{H} 9$ is accepted. The results of the analysis show that the product has a positive and significant effects on purchasing decisions through brand image. This means that the better the product, the more purchasing decisions through the brand image, and vice versa. 


\section{CONCLUSION}

The results of the study concluded that product price, promotion had an effect on purchasing decisions with brand image as an intervening variable an understanding of consumer behavior is very important to believe in a company's marketing strategy. Therefore, companies must not only fulfill and fulfill economic wants, but also social needs and other motivations that consumers expect.

a. The analysis results show that the product has a positive and significant effect on brand image. This means that the better the product, the better the brand image. The opposite happens when the product is not suitable.

b. The results of the analysis show that price has a positive and significant effect on brand image. This means that the more appropriate the product price, the more the brand image increases. The opposite happens when prices do not match.

c. The results of the analysis show that promotion has a positive and significant effect on brand image. This means that the better the promotion, the more the brand image will be. The opposite happens when promotion decreases.

d. The results of the analysis show that the product has a positive effect on purchasing decisions. This means that the better and more appropriate the product, the more purchasing decisions will increase. The opposite happens if the product decreases.

e. The results of the analysis show that the price has a positive effect on purchasing decisions. This means that the more appropriate the price, the more purchasing decisions increase. The opposite happens if prices do not match.

f. The results of the analysis show that promotion has a positive and significant effect on purchasing decisions. This means that the better the promotion, the more purchasing decisions will be made. The opposite happens if promotion decreases.

g. The results of the analysis show that brand image has a positive and significant effect on purchasing decisions. This means that the stronger the brand image, the higher the purchasing decision. The opposite happens if the brand image weakens.

h. The results of the analysis show that the product has a positive and significant effect on purchasing decisions through brand image. This means that the better the product, the more purchasing decisions through the brand image, and vice versa. i. The results of the analysis show that the price has a positive and significant effect on purchasing decisions through brand image. This means that the more appropriate the price, the higher the purchase decision through the brand image, and vice versa.

j. The results of the analysis show that promotion has a positive and significant effect on purchasing decisions through brand image. This means that the better the promotion, the higher the purchasing decision through the brand image, and vice versa.

\section{REFERENCES}

[1] S. Vikram. 2014, Analysis of Research in Consumer Behavioour oof Automobile Car Costumer. International journal of scientific and Research Publication.

[2] A. Mohammed et.al. (2010). Influence of Brand Name on Consumer Decision Making Process-An Empirical Study on Car Buyers. Journal Economic and Public Administration. Volume 2 (12), hlmn 142-153.

[3] A. Samuel Taiwo. 2010. The influence of work environment on workers productivity: A case of selected oil and gas industry in Lagos, Nigeria.

[4] K. Philip, Amstrong Gary. 2013. Prinsip-prinsip Pemasaran, Edisi ke-12. Penerbit Erlangga.

[5] W. H., Ivan, \& Darmawan, H. (2014). Analisis Faktor Fundamental Terhadap Harga Saham pada Perusahaan Manufaktur di BEI Periode 2009-2011. Jurnal Akuntansi,18.

[6] A. Byan. 2013.Pengaruh Kepemilikan Institusional, Ukuran Perusahaan, Pertumbuhan Perusahaan Dan Profitabilitas Terhadap Kebijakan Hutang Pada Perusahaan Basic Industry And Chemical di BEI Tahun 2009 - 2011. Skripsi Universitas Diponegoro.

[7] T, Fandy. 2014, Pemasaran Jasa - Prinsip, Penerapan, dan Penelitian, Andi Offset, Yogyakarta.

[8] D, Saladin. 2010. Manajemen Pemasaran, Edisi Pertama, Bandung, Linda Karya.

[9] S, ugioyno 2012. Metode Penelitian Kuantitatif, Kualitatif dan RD. Alfabeta Bandung.

[10] Tjiptono, Fandy. 2014, Pemasaran Jasa - Prinsip, Penerapan, dan Penelitian, Andi Offset, Yogyakarta.

[11] Purwati, dkk. 2012. "Pengaruh Harga dan Kualitas Produk Terhadap Keputusan Pembelian Motor 
Honda Matic Beat (Studi Kasus Pada PT. Nusantara Solar Sakti)". Jurnal Ekonomi dan Informasi Akuntansi (JENIUS) Politeknik Negeri Sriwijaya. Vol. 2 (3), 260-277.

[12] Ali, Hasan. 2013. Marketing dan Kasus-Kasus Pilihan. Yogyakarta. CAPS (Center For Academic Publishing Service 